\title{
Sistem Pakar Mengidentifikasi Minat Bakat Anak Dengan Metode Certainty Factor \\ (Studi Kasus : Sekolah Bilingual Nasional Plus Permata Bangsa Binjai)
}

\author{
Rusmin Saragih ${ }^{1}$, Muhammad Eka ${ }^{2}$ \\ ${ }^{1}$ STMIK Kaputama Binjai, Indonesia, \\ ${ }^{2}$ Universitas Nahdlatul Ulama Sumatera Utara, Indonesia \\ 1evitha12014@gmail.com, meckawijaya@gmail.com ${ }^{2}$
}

\begin{abstract}
Abstrak
Banyak orang tua yang cenderung memaksakan kehendaknya ketika memilih sekolah formal ataupun non formal untuk anaknya. Dikarenakan tidak mengetahui Minat dan bakat yang dimiliki oleh anaknya. Hal ini mengekibatkan anak akan sulit untuk berkembang. Dan sulitnya menemukan psikolog anak untuk berkonsultasi juga menjadi salah satu penyebab hal ini Sistem pakar mengidentifikasi minat bakat anak dibangun dengan bahasa pemrograman PHP dan database yang digunakan adalah Php MyAdmin (MySql). Sistem pakar harus mampu bekerja dalam kondisi ketidakpastian. Dalam menghadapi masalah, sering ditemukan jawaban yang tidak memiliki kepastian. Tinggi rendahnya tingkat ketidakpastian hasil identifikasi dipengaruhi oleh aturan yang tidak pasti dan jawaban pengguna. MetodeCertainty Factor yang merupakan suatu teori matematika untukmengakomodasi ketidakpastian pemikiran seorang pakar, guna mengggambarkan tingkat keyakinan pakar terhadap masalah yang sedang di hadapi.Hasil perhitungan diperoleh dari karakteristik yang ada, sehinggamenghasilkan identifikasi kecerdasan yang dimiliki oleh anak yaitu pada kecerdasan visual-spasial yang memiliki nilai kepastian paling kuat sebesar 99,60\%.
\end{abstract}

Kata Kunci : Minat, Bakat, Sistem Pakar, Certainty Factor.

\begin{abstract}
Many parents tend to impose their will when choosing formal or non-formal schools for their children. Because he could not see the interests and talents determined by his son. This results in children being difficult to develop. And the difficulty of finding a child psychologist to be used as one of the main causes of the identification system for child talent experts was built with the PHP programming language and the database used was Php MyAdmin (MySql). Expert systems must be able to work in conditions of uncertainty. When faced with problems, we often find answers that are not certain. The level of uncertainty of the results obtained by uncertain rules and user answers. The Certainty Factor method is a mathematical theory to accommodate the uncertainty of an expert's thinking, in order to describe the level of expert confidence in the problem at hand. The calculation results of the existing statements, so that the child's intelligence is the visual-spatial intelligence which has the strongest certainty value. of $99.60 \%$.
\end{abstract}

Keywords: Interest, Talent, Expert System, Certainty Factor.

\section{PENDAHULUAN}

\subsection{Latar Belakang Masalah}

Setiap anak dilahirkan dengan bakat yang berbeda antara satu dengan yang lainnya. Identifikasi bakat anak merupakan hal yang sangat penting dilakukan. Hal ini dikarenakan setiap anak memerlukan program pendidikan yang sesuai dengan bakat mereka masing-masing, sehingga dapat mengembangkan dan menggunakan bakat mereka secara maksimal. Disinilah peran orang tua untuk 
terlebih dahulu mengenal bakat anak dari kecil, kemudian mengarahkan dan mengembangkannya. Tujuan sekolah yang mendasar adalah mengembangkan bakat dan minat peserta didiknya sesuai dengan jenjang pendidikannya. Guru sebagai orang tua kedua bagi anak didiknya disekolah yang memiliki peran penting dalam pengembangan kemampuan anak didiknya.

Sekolah Bilingual Nasional Plus Permata Bangsa Binjai merupakan salah satu lembaga pendidikan berstandar nasional yang menggunakan dua bahasa, yaitu bahasa inggris dan bahasa indonesia. Untuk menciptakan sumber daya manusia yang berkualitas pihak sekolah selalu berusaha untuk memberikan yang terbaik dengan mempersiapkan segala sesuatu yang dibutuhkan untuk kegiatan belajar mengajar. Selama ini Sekolah Bilingual Nasional Plus Permata Bangsa Binjai melakukan evaluasi secara manual dan hanya untuk menentukan kecerdasan, belum sampai pada tingkat menentukan minat dan bakat anak. Sistem yang masih manual dirasa kurang efektif dan efisien dalam segi biaya dan waktu. Sehingga penulis memberikan satu solusi dengan melakuakan penelitian untuk memudahkan guru dalam menerapkan metode belajar yang tepat bagi siswa agar sesuai dengan minat dan bakat yang dimiliki.

Penelitian yang dilakukan oleh Laksana, dkk (2016), berjudul Analisa Bakat Anak Melalui Penerapan Sistem Pakar Dengan Metode Forward Chaining, yang menyatakan bahwa : "Mengenai permasalahan bakat anak, psikolog anak adalah salah satu tempat para orang tua untuk berkonsultasi tentang bakat yang dimiliki oleh anaknya. Namun, jumlah psikolog anak yang terbatas serta biaya konsultasi yang tidak murah membuat para orang tua mengurungkan niat untuk berkonsultasi. Pada akhirnya orang tua hanya menerka-nerka bakat anak, bahkan memaksakan kemampuan yang diinginkan oleh orang tua. Keinginan orang tua yang bertolak belakang dengan bakat alami yang dimiliki anak dapat menghambat prestasi anak. Untuk itu diperlukan analisa bakat anak agar dapat diketahui bakat dan minat anak sehingga anak dapat berkembang sesuai dengan keinginannya. Akar masalah dari penelitian ini adalah banyaknya bakat anak yang tidak tersalurkan dengan baik. Hal ini dikarenakan kurangnya pengetahuan para orang tua dalam menangani permasalahan bakat yang dimiliki anaknya, serta kurangnya pakar dalam mengatasi solusi terbaik dari permasalahan tersebut. Untuk itu diperlukan analisa terhadap bakat yang dimiliki anak".

Berdasarkan uraian diatas, maka topik yang diajukan untuk penulisan skripsi berjudul "Sistem Pakar Mengidentifikasi Minat Bakat Anak Dengan Metode Certainty Factor (Studi Kasus : Sekolah Bilingual Nasional Plus Permata Bangsa Binjai)".

\subsection{Rumusan Masalah}

Berdasarkan latar belakang masalah dapat diuraikan permasalahan yang ada yaitu:

1. Dengan merancang sistem pakar, bagaimana cara merancang sistem untuk menentukan minat bakat anak di Sekolah Bilingual Nasional Plus Permata Bangsa Binjai menggunakan motode certainty factor?

2. Dengan menerapkan metode certainty factor, bagaimana mengidentifikasi minat bakat anak berdasarkan karakteristik yang tampak pada anak?

\subsection{Tujuan Penelitian}

Adapun tujuan dari penyusunan skripsi ini adalah sebagai berikut:

1. Untuk merancang suatu sistem berbasis web yang dapat mengetahui minat bakat anak dan stimulasi yang tepat bagi anak.

2. Untuk menentukan faktor kepastian dan ketidakpastian dari minat bakat anak dengan menggunakan metode certainty factor.

\subsection{Manfaat Penelitian}

Adapun manfaat dari penyusunan skripsi ini adalah sebagai berikut:

1. Dapat memberikan kemudahan bagi pengguna untuk mendapatkan informasi mengenai minat bakat anak beserta karakteristiknya.

2. Membantu pengguna untuk mengenal dan menemukan minat bakat anak yang paling dominan sehingga dapat bermanfaat bagi anak dalam mengetahui stimulasi yang sesuai dengan kecenderungan minat bakat yang dimiliki. 
3. Mempermudah pengguna untuk mengetahui minat bakat anak tanpa harus bertemu psikolog karena waktu yang terbatas dan mahalnya biaya berkonsultasi dengan psikolog.

4. Dapat membantu psikolog dalam hal menangani minat bakat anak yang paling dominan.

\section{LANDASAN TEORI}

\subsection{Pengertian Sistem Pakar}

Menurut Sutojo,dkk (2011, h.13) sistem pakar adalah suatu sistem yang dirancang untuk dapat menirukan keahlian seorang pakar dalam menjawab petanyaan dan memecahkan masalah. Sistem pakar akan memberikan pemecahan suatu masalah yang didapat dari dialog dengan pengguna. Dengan bantuan sistem pakar seseorang yang bukan pakar/ahli dapat menjawab pertanyaan, menyelesaikan masalah serta mengambil keputusan yang biasanya dilakukan oleh seorang pakar.

\subsection{Pengertian Minat dan Bakat}

Menurut Sefriana (2013, h.28) minat merupakan ketertarikan akan sesuatu objek yang berasal dari hati, bukan karena paksaan dari orang lain.Dalam Kamus Besar Bahasa Indonesia(KBBI), Minat berarti kecenderungan hati yang tinggi terhadap sesuatu, diartikan pula sebagai gairah keinginan. Dalam bahasa Inggris, minat sering digambarkan dengan kata-kata "Interest" atau "Passion". "Interest" bermakna suatu perasaaan ingin memperlihatkan dan penasaran akan suatu hal, sedangkan "Passion" sama maknanya dengan gairah atau suatu perasaan yang kuat atau antusiasme terhadap sesuatu objek.

Sedangkan bakat dalam Kamus Besar Bahasa Indonesia (KBBI), kata bakat diartikan sebagai kepandaian, sifat dan pembawaan yang dibawa sejak lahir. Dalam bahasa Inggris, bakat sering digambarkan dengan kata "talent", yang berarti kemampuan alami seseorang yang luar biasa akan sesuatu hal atau kemempuan seseorang yang di atas rata-rata kemampuan orang lain akan sesuatu hal.

\subsection{Pengertian Certainty Factor}

Menurut Sutojo, dkk (2011, h.194) Teori Certainty Factor (CF) diusulkan oleh Shortliffe dan Buchanan pada 1975 untuk mengakomodasi ketidakpastian pemikirian (inexact reasoning) seorang pakar. Seorang pakar, (misalnya dokter) sering kali menganalisis informasi yang ada dengan ungkapan seperti "mungkin", "kemungkinan besar", "hampir pasti". Untuk mengakomodasi hal ini kita menggunakan certainty factor $(C F)$ guna menggambarkan tingkat keyakinan pakar terhadap masalah yang sedang di hadapi.

Menurut kusrini bentuk dasar rumus Certainty factor sebuah aturan jika E maka $\mathrm{H}$ ditunjukan oleh rumus dibawah ini (Mukafi, 2018):

$$
\mathrm{CF}[\mathrm{H}, \mathrm{e}]=\mathrm{CF}[\mathrm{E}, \mathrm{e}] * \mathbf{C F}[\mathrm{H}, \mathrm{E}]
$$

Keterangan :

1. $\mathbf{C F s}[\mathbf{E}, \mathbf{e}]$ : Certainty Factor evidence $\mathrm{E}$ yang dipengaruhi oleh evidence e.

2. $\mathbf{M B}[\mathbf{H}, \mathbf{E}]$ : Certainty factor hipotesis dengan asumsi evidence diketahui dangan pasti yaitu ketika $\mathrm{CF}(\mathrm{E}, \mathrm{e})=1$.

3. $\mathbf{M D}[\mathbf{h}, \mathbf{e}]$ : Certainty factor hipotesis yang dipengaruhi oleh evidence e.

Certainty factor merupakan CF akhir dari sebuah calon konklusi. CF ini dipengaruhi oleh semua CF paralel dari aturan yang menghasilkan konklusi tersebut. Certainty factor gabungan diperlukan jika suatu konklusi diperoleh dari beberapa aturan sekaligus. Berikut ini merupakan rumusan perhitungan untuk certainty factor gabungan :

$$
\mathrm{CF}(\mathrm{CF} 1, \mathrm{CF} 2)= \begin{cases}C F 1+C F 2(1-C F 1) & \text { if } C F 1>0 \text { dan } C F 2>0 \\ \frac{C F 1+C F 2}{(1-[|C F 1|,|C F 2|])}, & \text { if } C F 1<0 \text { or } C F 2<0 \\ C F 1+C F 2(1+C F 1) & \text { if } C F 1<0 \text { dan } C F 2<0\end{cases}
$$


Untuk mendapatkan keyakinan dapat dengan cara mewawancarai seorang pakar dengan aturan $\mathrm{CF}($ Rule). Sedangkan untuk menentukan nilai tingkat keyakinan dari user juga dapat menggunakan aturan yang sama. Nilai $\mathrm{CF}($ Rule $)$ dapat di

interpretasi dengan "term" dari pakar, yang diubah menjadi nilai tertentu sesuai table berikut :

Tabel II.2 Interpretasi Nilai CF

\begin{tabular}{|c|c|}
\hline Uncertain Term & CF \\
\hline Definitely not (pasti tidak) & -1.0 \\
\hline Almost certainly not (hampir pasti tidak) & -0.8 \\
\hline Probably not (kemungkinan besar tidak) & -0.6 \\
\hline Maybe not (mungkin tidak) & -0.4 \\
\hline Unknown (tidak tahu) & -0.2 to 0.2 \\
\hline Maybe (kemungkinan) & 0.4 \\
\hline Probably (kemungkinan besar) & 0.6 \\
\hline Almost certainly (hampir pasti) & 0.8 \\
\hline Definitely (pasti) & 1.0 \\
\hline
\end{tabular}

Sumber : (Sutojo, dkk, 2011)

\section{ANALISIS DAN PERANCANGAN SISTEM}

\subsection{Metode Penelitian}

Metodologi penelitian ini dilakukan untuk mencari sesuatu secara sistematis dengan menggunakan metode ilmiah serta sumber yang berlaku. Dengan adanya proses ini dapat memberikan hasil penelitian yang baik dan tepat. Atas dasar metodologi penelitian yang digunakan, dapat dibuat suatu alur kegiatan seperti gambar III.1 sebagai berikut:

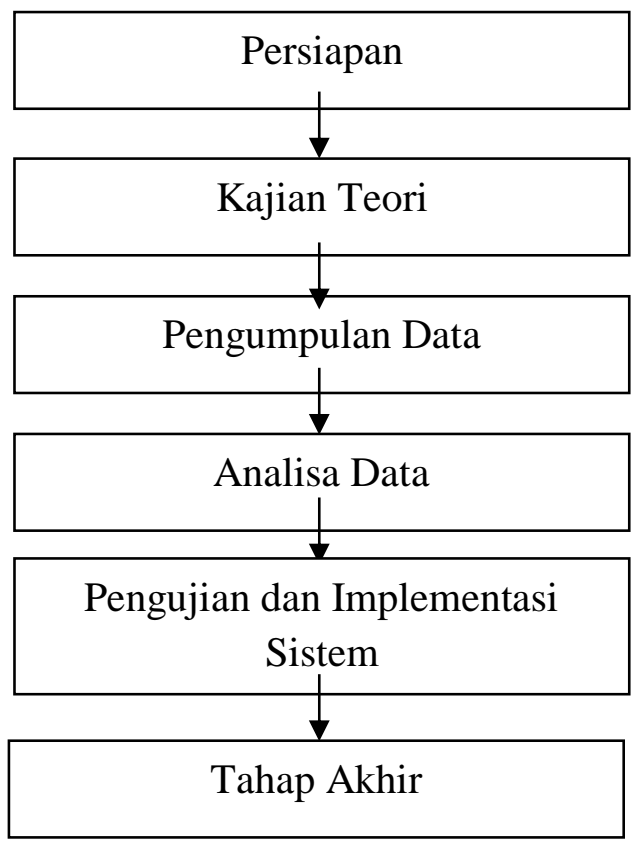

Gambar III.1 Alur Kerja Penelitian 


\subsection{Analisis Sistem}

Berdasarkan identifikasi masalah dapat disimpulkan bahwa prinsip kerja pada sistem pakar untuk mengidentifikasi minat bakat anak adalah sebagai berikut:

1. Membuat basis pengetahuan yang mampu menampung data ciri-ciri yang dimiliki anak.

2. Membangun basis pengetahuan untuk menganalisa suatu masalah tertentu dan selanjutnya akan mencari minat bakat yang dimiliki oleh anak.

3. Merancang antar muka pemakai yang dapat menjangkau semua kebutuhan pengguna tanpa mempersulit user dalam penggunaan sistem.

\subsection{Perancangan Sistem}

Dalam merancang suatu sistem pakar identifikasi minat bakat anak penulis menggunakan metode certainty factor untuk menyelesaikan masalah, sistem identifikasi yang dirancang yaitu menyesuaikan ciri-ciri yang dimiliki anak dengan kesimpulan data yang didapat dan dikumpulkan ke dalam database, Adapun rancangan flowchart seperti gambar berikut :

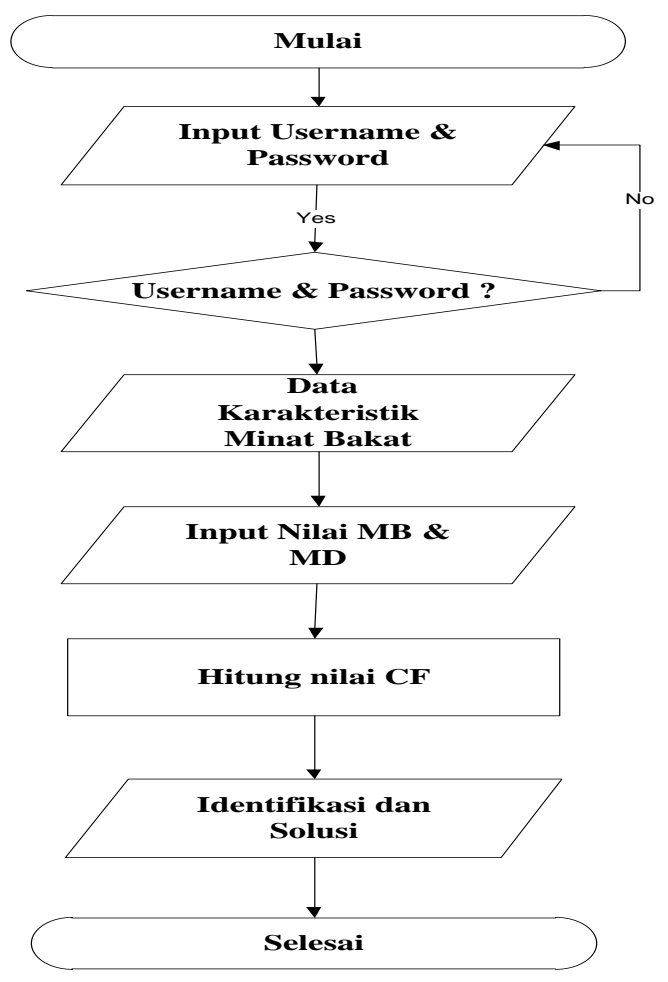

Gambar III.2 Flowchart Mengidentifikasi Minat Bakat Anak

\subsection{Rancangan Use Case Diagram}

Selanjutnya untuk memahami bagaimana sistem yang nantinya akan dibangun dapat dilihat proses sistem secara garis besar melalui unified modeling langguage(UML) seperti diagram use case berikut ini. 


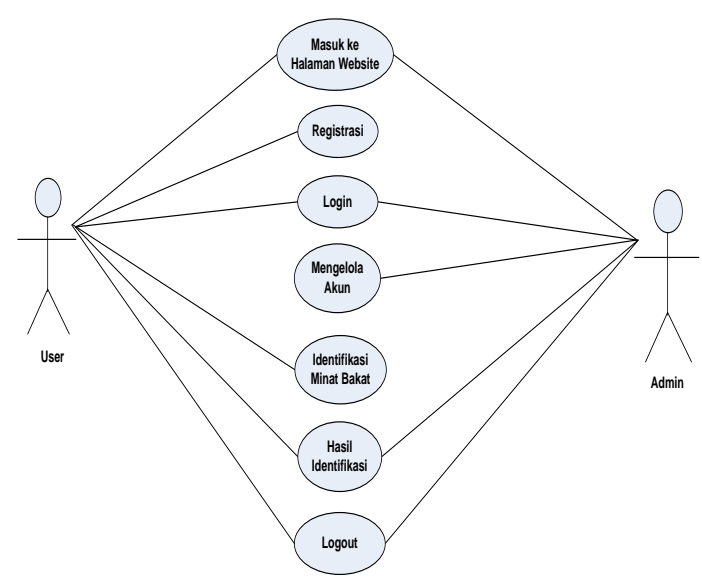

Gambar III.3 Usecase Diagram Mengidentifikasi Minat Bakat Anak

\section{PEMBAHASAN DAN IMPLEMENTASI}

\subsection{Pembahasan}

Berdasarkan hasil analisa dan perancangan yang telah dicapai maka dapat diterapkan aplikasi sistem pakar identifikasi minat bakat anak berbasis Web, dimana dalam aplikasi ini pengguna dapat masuk dan kemudian menggunakan halaman website untuk mengetahui kecerdasan yang dimiliki oleh anak serta bisa mengetahui stimulasi yang tepat untuk membantu mengoptimalkan kecredasan yang dimiliki anak tanpa harus menemui seorang ahli (pakar) psikolog.

\subsection{Manual Program}

Berikut ini adalah tampilan hasil dari perancangan sistem pakar mengidentifikasi minat bakat anak. Berikut keterangannya :

\section{Menu Utama}

Berikut ini desain tampilan interface menu utama pengguna

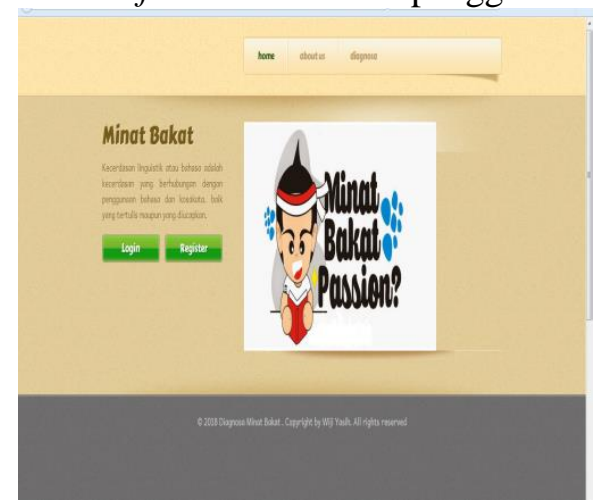

Gambar IV.1 Halaman menu utama

\section{Halaman Login}

Berikut adalah desain tampilan interface login sistem.

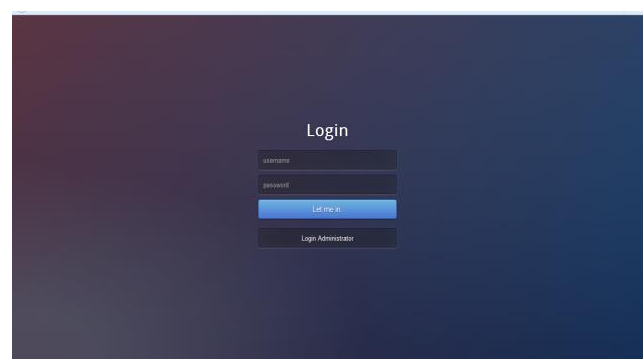

Gambar IV.2 Halaman login sistem 


\section{Halaman Registrasi}

Berikut adalah desain tampilan interface halaman registrasi.

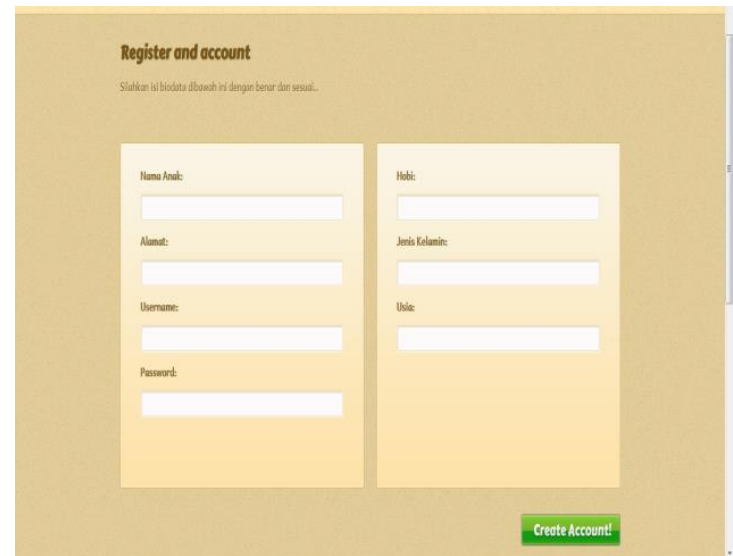

Gambar IV.3 Halaman registrasi

\section{Form konsultasi}

Halaman ini merupakan halaman untuk mengidentifikasi minat bakat anak pengguna atau user melalui konsultasi yang ada pada diri pengguna atau user. Berdasarkan dari pertanyaan minat bakat anak yang diberikan yang kemudian akan dipilih oleh pengguna atau user.

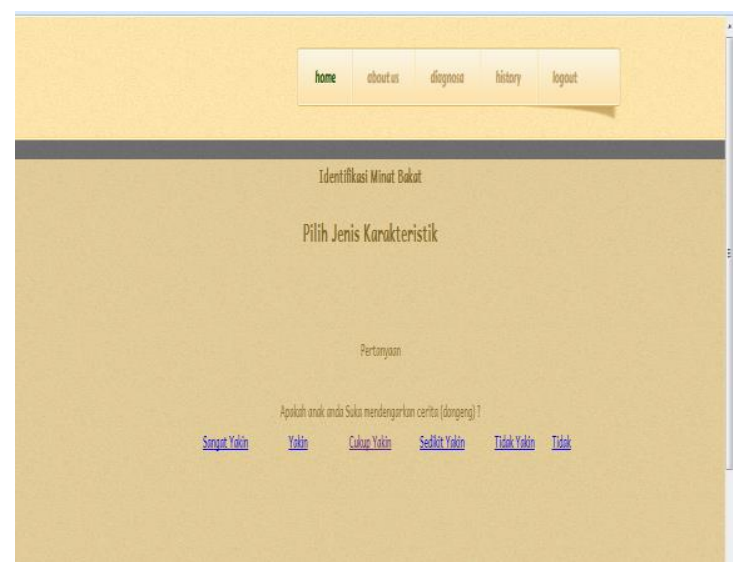

\section{Gambar IV.4 Form konsultasi}

\section{Form Basis Pengetahuan}

Halaman ini kemudian akan muncul ketika pengguna atau user selesai menjawab pertanyaan yang telah diberikan. Pengguna atau user akan mengetahui hasil dari konsultasi yang telah dilakukan. 


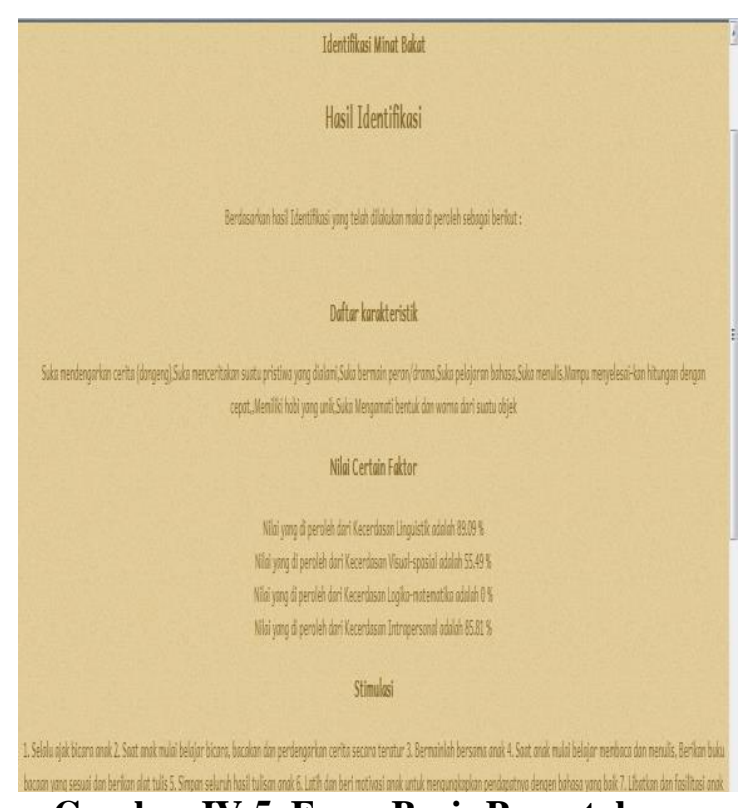

Gambar IV.5 Form Basis Pengetahuan

\section{Form Report Konsultasi}

Halaman ini selanjutnya akan tampil apabila pengguna atau user telah melakukan selesai dan ingin membuat report dari hasil konsultasi ya telah dilakukan.

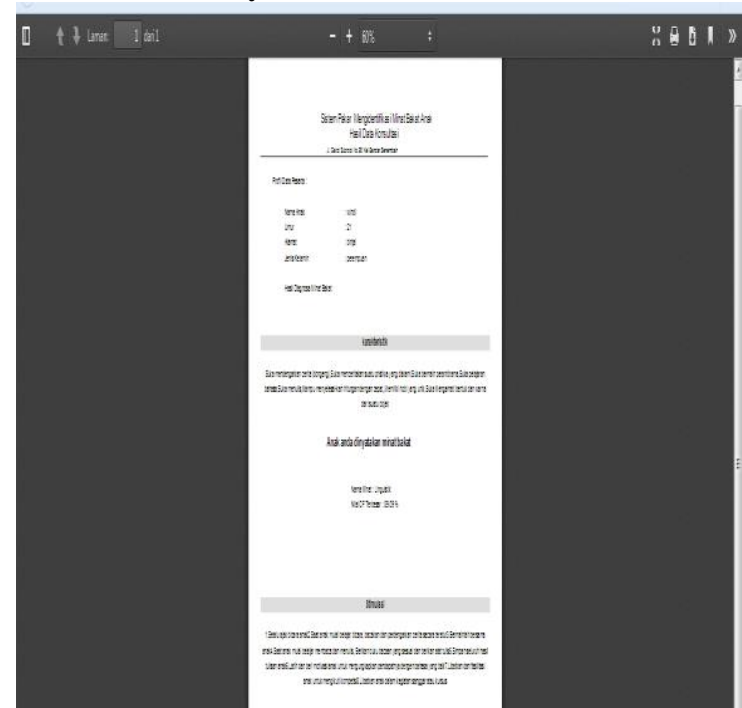

Gambar IV.6 Form Report Konsultasi

\section{KESIMPULAN DAN SARAN}

\subsection{Kesimpulan}

Berdasarkan hasil analisa yang telah dilakukan oleh penulis maka dapat ditarik kesimpulan sebagai berikut :

1. Dengan dibangunnya sistem pakar ini sebagai alat bantu dalam menentukan minat bakat anak di sekolah Billingual Nasional Plus Permata Bangsa menggunakan metode Certainty Factor berbasis web berdasarkan karakteristik yang dialami oleh pengguna atau user.

2. Dengan dibangunnya sistem ini dapat mengurangi biaya konsultasi dari segi waktu maupun biaya untuk mendapatkan informasi dan penanganan yang tepat tentang minat bakat pada anak.

3. Dengan diterapkannya sistem pakar identifikasiminat bakat pada anak berbasis web ini akan sangat membantu masyarakat umum untuk dapat berkonsultasi tentang minat bakat anak 
tanpa harus menemui psikolog serta akses yang dapat dijangkau kapanpun dan dimanapun pengguna atau user berada.

\subsection{Saran}

Dari hasil penelitian sistem pakar identifikasi minat bakat pada anak menggunakan metode Certainty Factor berbasis web adapun saran-saran yang dapat diberikan untuk proses pengembangannya sebagai berikut :

1. Sistem pakar mengidentifikasi minat bakat anak yang dibuat masih berupa program sederhana, dan dapat dikembangkan lagi gejala-gejala dan nilai keyakinan yang terbaru sehingga dapat mencapai keakuratan data.

2. Sistem pakar mengidentifikasi minat bakat anak ini membahas 4 kecerdasan yaitu Linguistik, Visual-Spasial, Logika Matematika, dan Intrapersonal. Dan masih dapat dikembangkan dengan menambahkan jenis kecerdasan yang lainnya.

3. Menggunakan metode yang lain sebagai pembanding.

\section{DAFTAR PUSTAKA}

Anhar. 2010. Panduan Menguasai PHP \& MySQL Secara Otodidak. MediaKita, Jakarta.

Buaton,Relita. 2013. Mudahnya Membuat Website. Andi, Yogyakarta.

Jogianto. 2005. Analisis dan Desain. Andi, Yogyakarta.

Kusrini, 2006. Sistem Pakar Teori dan Aplikasi. Andi, Yogyakarta.

Kusumadewi, Sri. 2003. Artificial Intelegence. Graha Ilmu, Yogyakarta.

Laksana, Tri Ginanjar, dkk. 2016. Analisa Bakat Anak Melalui Penerapan Sistem Pakar Dengan Metode Forward Chaining, Cirebon:Prosiding Seminar Nasional.

Lestari, Surip Anita, dan Handayani Rani Irma. 2017. Sistem Pakar Untuk Menentukan Bakat Anak Berdasarkan Kepribadian Menggunakan Model Forward Chaining. Jakarta:BINA INSANI ICT JOURNAL.

Mukafi, Muhamad Hamdan. 2018. Pengembangan Sistem Diagnosa Awal Gangguan Kesehatan pada Ayam Potong Menggunakan Metode Certainty Factor. Malang : Politeknik Negeri Malang.

Oetomo, Budi Sutejo Dharma. 2006. Perencanaan dan Pembangunan Sistem Informasi. Andi, Yogyakarta.

Sefrina, Andin. 2013. Deteksi Minat Bakat Anak. Media Pressindo, Yogyakarta.

Setiawan, Nanda Surya, dkk. 2013. Sistem Pakar Untuk Mendiagnosis Kecerdasan Majemuk Menggunakan Metode Fuzzy Expert System. Surabaya : STIKOM Surabaya.

Sugiarti,Yuni. 2012.Analisis \& Perancangan UML (Unified Modeling Language) Generated VB.6.Graha Ilmu, Yogyakarta.

Sutojo,T,dkk. 2011. Kecerdasan Buatan.Penerbit Andi, Yogyakarta.

Turban,Efraim, dkk. 2005.Decision Support Systems and Intelligent Systems. Andi, Yogyakarta.

Yatini, Indra, B. 2010. Flowchart, Algoritma, dan Pemrograman Menggunakan Bahasa C++ Builder. Graha Ilmu, Yogyakarta.

Yulianti, Wita. 2016. Aptitude Testing Berbasis Case-Based Reasoning Dalam Sistem Pakar Untuk Menentukan Minat Dan Bakat Siswa

Sekolah Dasar. Pekan Baru : UNIVRAB. 